\title{
"Ganhamos a batalha, mas não a guerra": a visão da Campanha Nacional contra a Alca sobre a não-assinatura do acordo
}

Suylan de Almeida Midlej e Silva

Curso: Doutorado em Sociologia

Data da defesa: 19 de agosto de 2008

Orientadora: Prof ${ }^{\mathrm{a}}$. Dr ${ }^{\mathrm{a}}$. Maria Francisca Pinheiro Coelho

\section{Resumo}

Este trabalho faz uma reflexão sobre o agir político dos movimentos sociais contemporâneos a partir da Campanha Nacional contra a Área de Livre Comércio das Américas (Alca), rede de organizações da sociedade civil que nasce com o objetivo de impedir a assinatura do acordo. A pesquisa mostra como esse movimento, ao mesmo tempo local e global, integra o Movimento por uma Nova Globalização, categoria geral de análise deste estudo. Com base na discussão dos conceitos de movimento social, rede 
de movimentos sociais e democracia radical, o trabalho demonstra como o movimento social contemporâneo resgata a esfera pública por meio das suas ações. O Plebiscito Popular sobre a Alca, que obteve mais de 10 milhões de votos, é analisado e apresentado como uma dessas ações e, na visão dos representantes da campanha, foi a principal influência no posicionamento do governo brasileiro para a não-assinatura do acordo, sendo menor a influência do Parlamento nessa decisão. Para este trabalho, realizou-se uma pesquisa empírica, na qual se utilizaram os seguintes procedimentos metodológicos: observação participante, entrevistas individuais semi-estruturadas, grupos focais e pesquisa documental. Foram realizadas 28 entrevistas em sete grupos, perfazendo um total de 72 entrevistados.

Palavras-chave: movimento social; democracia radical; plebiscito popular; Alca. 